\title{
Pengaruh Setting Parameter pada Slicing Software terhadap Surface Roughness Objek 3D Printing Menggunakan Metode Taguchi
}

\author{
Hasdiansah*, Sugiyarto \\ Teknik Mesin, Politeknik Manufaktur Negeri Bangka Belitung \\ Kawasan Industri Air Kantung, Bangka, 33211, Indonesia, Tel: 0717-93586, Fax: 0717-93585 \\ *Email: phiannttarah@yahoo.co.id
}

Diterima: 15-03-2021; Direvisi: 21-11-2021; Dipublikasi: 30-12-2021

\begin{abstract}
Abstrak
Teknologi FDM (Fused Deposition Modelling) merupakan salah satu teknologi yang digunakan untuk membuat objek 3D. FDM sering disebut sebagai teknologi yang sudah mampu mengubah dunia manufaktur dewasa ini. Namun teknologi FDM memiliki kelemahan karena teknologi ini menggunakan proses building per layer membuat permukaan yang dihasilkan terlihat memiliki garis yang menunjukan batas antar layer sehingga mempengaruhi kekasaran pada permukaan produk cetak. Penelitian ini menggunakan filamen Super Tough PLA (ST.PLA). Tujuan penelitian ini adalah untuk mengetahui pengaruh parameter proses terhadap kekasaran permukaan objek cetak dan untuk mengetahui seting parameter proses yang menghasilkan kekasaran permukaan terbaik dari parameter proses yang digunakan. Penelitian ini menggunakan metode Taguchi dengan matriks ortogonal $\mathrm{L}_{25}\left(5^{6}\right)$. Parameter proses yang akan dipilih dan dianalisis dalam penelitian ini adalah layer thickness, printing speed, nozzle temperature, orientation, flowrate, cooling speed dan respon yang diamati adalah kekasaran permukaan objek cetak. Untuk mengatasi permasalahan noise (gangguan) maka dicetak masing-masing tiga kali replikasi Selanjutnya parameter proses tersebut akan dianalisis menggunakan Analisis Varian (ANOVA). Berdasarkan data hasil pengukuran kekasaran permukaaan objek cetak, maka diperoleh parameter proses yang memberikan pengaruh paling besar terhadap kekasaran permukaan objek cetak dengan menggunakan filamen ST-PLA adalah layer thickness dengan nilai F hitung sebesar 129,96, flowrate dengan nilai F hitung sebesar 6 dan orientation dengan nilai F hitung sebesar 3,03. Seting parameter proses yang menghasilkan nilai kekasaran permukaan terbaik objek cetak adalah $0,10 \mathrm{~mm}$ yaitu pada eksperimen nomor lima (Exp. No. 5) dengan rata-rata $12,61 \mu \mathrm{m}$, dengan pengaturan layer thickness, 45 $\mathrm{mm} / \mathrm{s}$ pada pengaturan printing speed, $210^{\circ} \mathrm{C}$ pada nozzle temperature, $0^{\circ}$ pada orientation, $110 \%$ pada pengaturan flowrate dan $40 \%$ pada pengaturan cooling speed. Seluruh parameter proses tersebut disetting pada slicing software ideamaker 3.6.1. dalam menghasilkan G-Code objek cetak.
\end{abstract}

Kata kunci: 3D Printing, FDM, Filament ST-PLA, Kekasaran Permukaan, Taguchi

\begin{abstract}
FDM (Fused Deposition Modeling) technology is one of the technologies used to create 3D objects. FDM is often referred to as a technology that has been able to change today's manufacturing world. However, FDM technology has a weakness because this technology uses a building per layer process to make the resulting surface appear to have lines that show the boundaries between layers so that it affects the roughness of the surface of the printed product. This study used Super Tough PLA (ST.PLA) filament. The purpose of this study is to determine the effect of process parameters on the surface roughness of the printed object and to determine the process parameter settings that produce the best surface roughness of the process parameters used. This study uses the Taguchi method with an orthogonal matrix $L 25\left(5^{6}\right)$. The process parameters that will be selected and analyzed in this study are layer thickness, printing speed, nozzle temperature, orientation, flowrate, cooling speed and the observed response is the surface roughness of the printed object. To overcome the noise problem, three replications were printed each. Furthermore, the process parameters were analyzed using Analysis of Variance (ANOVA). Based on the results of the measurement of the surface roughness of the printed object, the process parameters that have the greatest influence on the surface roughness of the printed object using the ST-PLA filament are layer thickness with a calculated $F$ value of 129.96, flowrate with a calculated $F$ value of 6 and orientation with a calculated $F$ value of 3.03. The process parameter setting that produces the best surface roughness value for the printed object is $0.10 \mathrm{~mm}$, namely in experiment number five (Exp. No. 5) with an average of $12.61 \mathrm{~m}$, with the layer thickness setting, $45 \mathrm{~mm} / \mathrm{s}$ at the printing speed setting., $210^{\circ} \mathrm{C}$ on the nozzle temperature, $0^{\circ}$ on the orientation, $110 \%$ on the flowrate setting and $40 \%$ on the cooling speed setting. All process parameters are set in the ideamaker slicing software 3.6.1. in generating G-Code print objects.
\end{abstract}

Keywords: 3D Printing, FDM, Filament ST-PLA, Surface Roughness, Taguchi 
Hasdiansah dkk. /Jurnal Rekayasa Mesin p-ISSN: 1411-6863, e-ISSN: 2540-7678

Vol.16|No.3|318-328|Desember|2021

\section{Pendahuluan}

Teknologi FDM (Fused Deposition Modelling) merupakan salah satu teknologi untuk membuat objek 3D. 3D Printing sering disebut sebagai teknologi terbaru yang akan mampu mengubah dunia. Salah satu teknologi 3D printing yang sering ditemukan dan teknologi 3D Printing yang paling murah saat ini adalah jenis teknologi FDM. Prinsip kerja FDM (Fused Desposition Modeling) adalah dengan cara ekstrusi thermoplastic melalui nozzle yang panas pada melting temperature selanjutnya produk dibuat lapis per lapis hingga selesai dan terbentuk menjadi produk jadi atau prototype. Suzen Z.S. dan Hasdiansah H, telah mealkukan penelitian menggunakan filamen PLA+ terhadap kuat tarik spesimen uji tarik standar ASTM D638 Type IV menunjukkan bahwa bentuk geometri infill mempengaruhi kuat tarik spesimen uji.[1] Altan $\mathrm{M}$ et al., telah meneliti menggunakan filamen PLA dengan menggunakan metode Taguchi LOA16. [2] Hafsa M. N et al., telah meneliti material ABS dan PLA menggunakan parameter layer thickness terhadap akurasi dimensi dan surface roughness objek cetak, menunjukkan bahwa layer thickness memberikan pengaruh yang dominan terhadap akurasi dimensi dan surface roughness.[3] Buj-Corral I, et al., telah meneliti material PLA dalam bentuk setengah bola dengan menggunakan teknologi Fused Deposition Modelling (FDM), menunjukkan bahwa layer height dan diameter nozzle mesin 3D Printer memberikan pengaruh terhadap surface roughness objek cetak.[4] Charles A et.al., telah meneliti tentang surface roughness objek cetak dengan menggunakan teknologi Selective Laser Melting (SLM) material serbuk PLA, menunjukkan bahwa parameter yang disetting pada mesin 3D Printer berteknologi SLM memberikan pengaruh terhadap tingkat surface roughness objek cetak. [5] García Plaza E, et.al., telah meneliti dengan menggunakan material PLA terhadap akurasi dimensi produk cetak, menunjukkan bahwa semakin tipis layer thickness maka semakin akurat produk cetak dan pengaruh feed rate mesin 3D Printer tidak memberikan dampak yang dominan terhadap akurasi dimensi produk cetak [6].

Berdasarkan hasil penelitian yang telah dilakukan Taufik, et al., telah melakukan penelitian tentang pengaruh Printing Speed terhadap tingkat kekasaran permukaan hasil Additive Manufacturing menggunakan filament PLA. Penelitian ini menggunakan printing speed dengan tiga variasi yaitu 50\% (spesimen ke-1), 100\% (spesimen ke-2) dan $150 \%$ (spesimen ke-3). Penelitian ini mendapatkan hasil bahwa nilai rata - rata hasil pengukuran tingkat kekasaran permukaan cenderung meningkat (semakin kasar) jika printing speed semakin ditingkatkan [7].

Penelitian yang telah dilakukan Pristiansyah, et al., telah melakukan penelitian tentang akurasi dimensi objek cetak dengan menggunakan filamen Eflex. Dalam penelitian ini menggunakan parameter proses yang diatur pada slicing software dalam menghasilkan G-Code adalah flow rate, layer thickness, nozzle temperature, printing speed, overlap dan fan speed. Hasil yang didapatkan dari penelitian ini adalah parameter proses yang optimal untuk mendapatkan keakuratan dimensi arah $\mathrm{X}$ adalah flow rate $110 \%$, layer thickness $0,10 \mathrm{~mm}$, nozzle temperature $210^{\circ} \mathrm{C}$, print speed 40 $\mathrm{mm} / \mathrm{s}$, overlap $75 \%$ dan fan speed $50 \%$. Untuk dimensi arah Y adalah flow rate $120 \%$, layer thickness 0,20 mm, nozzle temperature $230^{\circ} \mathrm{C}$, print speed $30 \mathrm{~mm} / \mathrm{s}$, overlap $75 \%$ dan fan speed $100 \%$. Serta dimensi arah Z adalah flow rate $120 \%$, layer thickness $0,30 \mathrm{~mm}$, nozzle temperature $210^{\circ} \mathrm{C}$, print speed $30 \mathrm{~mm} / \mathrm{s}$, overlap $50 \%$ dan fan speed 100 $\%$.[8] Penelitian yang telah dilakukan Hakim, et al., telah meneliti tentang pengaruh temperatur nozzle dan base plate menggunakan material PLA terhadap nilai masa jenis dan kekasaran permukaan produk pada mesin leapfrog creater 3D printer. Penelitian ini menggunakan tiga variasi temperatur nozzle yaitu $190^{\circ} \mathrm{C}, 205^{\circ} \mathrm{C}, 220^{\circ} \mathrm{C}$ dan menggunakan dua variasi temperatur bed $30^{\circ} \mathrm{C}, 50^{\circ} \mathrm{C}$. Dari penelitian ini didapatkan hasil kekasaran permukaan terbaik pada pengaturan temperatur nozzle $190^{\circ} \mathrm{C}$ dan temperatur bed $30^{\circ} \mathrm{C}$ dengan menggunakan lem sebesar $5.709 \mu \mathrm{m}$ [9].

Penelitian yang lain oleh Karuniawan, et al., telah melakukan penelitian tentang 3D Printing berteknologi Fused Deposition Modelling (FDM). DOE penelitian ini menggunakan metode Taguchi dengan menggunakan parameter 
printing speed, printing temperature dan layer height. Penelitian ini memperoleh hasil bahwa layer height memiliki kontribusi paling dominan terhadap nilai kekasaran permukaan objek cetak, sedangkan printing temperature menempati posisi dua dan yang ketiga adalah printing speed.[10] Sahputra, et al., telah melakukan penelitian terhadap material ABS untuk memperoleh tingkat kehalusan permukaan objek cetak dengan mengunakan 3D Printing. Dalam penelitian ini menggunakan tiga parameter temperatur seting nozzle yaitu $240^{\circ} \mathrm{C}, 250^{\circ} \mathrm{C}$ dan $260^{\circ} \mathrm{C}$ (single nozzle dan dual nozzle) temperatur base plate $30^{\circ} \mathrm{C}$, dan $100^{\circ} \mathrm{C}$ serta adhesive type dengan lem atau tanpa lem. Berdasarkan hasil pengukuran nilai kekasaran permukaan objek cetak pada penelitian ini didapatkan hasil bahwa temperatur terbaik dalam mencetak adalah dengan menggunakan temperatur nozzle $240^{\circ} \mathrm{C}$ dan base plate $30^{\circ} \mathrm{C}$.[11] Yang. et.al., telah meneliti parameter 3D Printing berteknologi FDM dengan metode RSM dengan menggunakan lima parameter yaitu (nozzle diameter, liquefier temperature, extrusion velocity, filling velocity and layer thickness) terhadap kuat tarik spesimen uji dan kekasaran permukaan objek 3D Printing, menunjukkan hasil bahwa optimalisasi parameter teresebut signifikan terhadap kualitas kekasaran permukaan dan efisiensi proses.[12] Nadir Ayrilmis, telah meneliti tentang kekasaran permukaan objek cetak 3D Printing dengan menggunakan filamen PLA Wood dengan empat variasi layer thickness, 0,05mm, 0,1 mm, 0,2 mm, dan 0,3mm menunjukkan bahwa semakin tipis layer thickness maka semakin hasil produk yang dihasilkan. [13] Yang H. Et.al., telah meneliti material PLA dan ABS pada pembuatan hydrophobics coating, dengan menggunakan parameter layer thickness $0,25 \mathrm{~mm}$, printing speed $150 \mathrm{~mm} / \mathrm{s}$, dan infill grid menunjukkan hasil bahwa layer thickness dan infill mempengaruhi tingkat kekasaran permukaan produk cetak, sementara printing speed tidak memberikan pengaruh terhadap kekasaran permukaan produk cetak.[14] Heshmat M, et.al., telah meneliti dengan menggunakan faktor building orientation; layer thickness; and impact angle of the slurry particles pada mesin 3D Printer berteknologi FDM menunjukkan bahwa keempat faktor pada penelitian tersebut memberikan pengaruh yang signifikan terhadap kekasaran permukaan objek yang dicetak [15].

Penelitian ini menggunakan filament ST-PLAyang merupakan pengembangan dari material PLA murni. Penelitian ini menggunakan filament ST-PLA dikarenakan filament ST-PLA banyak digunakan oleh para penggemar 3D Printing dan peneliti. Walaupun ST-PLA mudah rapuh setelah beberapa bulan dikarenakan oleh kelembapan suhu dan debu. Namun masih sangat perlu untuk diteliti dari segi tingkat kehalusan produk cetaknya.Selain itu waktu pelapukannya pun membutuhkan waktu berkisar enam (6) bulan. Produsen filamen CCTREE memproduksi PLA special yang disebut ST-PLA atau Super Tough PLA yang dikomposkan dengan aditif special, PLA ini tidak berpengaruh biodegradasi, dan dapat meningkatkan sifat mekanik PLA dibanding dengan filament PLA normal. Filament ST-PLA lebih keras dibandingkan dengan PLA biasa, sehingga dapat menghasilkan kekuatan yang lebih baik, ikatan lapisan yang kuat dan lebih tahan akan benturan. Penelitian ini bertujuan untuk memperoleh pengaturan parameter proses terbaik terhadap tingkat kekasaran permukaan objek cetak menggunakan filamen ST-PLA yang disetting pada slicing software dalam bentuk G-Code.

\section{Metode Penelitian}

Tahapan penelitian yang dilakukan dimulai dari studi pustaka yang berkaitan dengan penelitian terkait filamen PLA, terutama pada penelitian kekuatan tarik produk 3D Printing. Pemilihan parameter proses yang digunakan pada pembuatan atau pencetakan spesimen uji kekasaran permukaan, selanjutnya menentukan Design Of Experiment (DOE). Penentuan level tiap faktor, sehingga menghasilkan Orthogonal Array berdasarkan desain Taguchi. Selanjutnya parameter proses yang dipilih digunakan pada slicing software dalam menghasilkan G-Code spesimen uji kekasaran 
permukaan sebanyak dua puluh lima (25) eksperimen. Masing-masing Eksperimen dicetak tiga (3) spesimen uji kekasaran permukaan.

\subsection{Objek Penelitian}

Objek penelitian dilakukan pada mesin 3D Printer dengan volums XYZ dengan dimensi $300 \mathrm{~mm}$ x $300 \mathrm{~mm}$ x 350 mm dengan menggunkan nozzle berukuran 0,4 mm. material yang digunakan fillament ST-PLA dengan diameter 1,75 mm. Desain objek dibuat menggunakan software gambar dengan bentuk dan dimensi berdasarkan spesimen pengujian seperti pada Gambar 1.
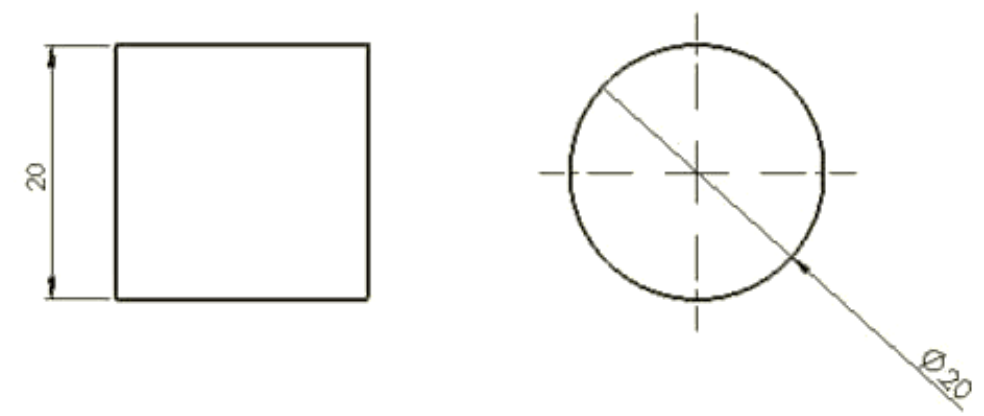

Gambar 1. Dimensi dan Bentuk Spesimen Uji Kekasaran Permukaan

\subsection{Alat dan Bahan}

Alat dan Bahan Mesin 3D Printer FDM Anet 8 plus dengan printing volums XYZ dengan dimensi $300 \mathrm{~mm} \times 300$ mm x $350 \mathrm{~mm}$ yang digunakan untuk mencetak spesimen seperti pada Gambar 2. Filamen ST-PLA dengan diameter 1,75 mm seperti pada Gambar 3(a). Spesimen uji kekasaran permukaan seperti pada Gambar 3(b). Slicing Software ideamaker 3.6.1, digunakan untuk menghasilkan G-Code pada mesin 3D Printing. Mitutoyo Surface Roughness Tester sebagai alat ukur kekasaran permukaan spesimen uji ditunjukkan seperti pada Gambar 4.

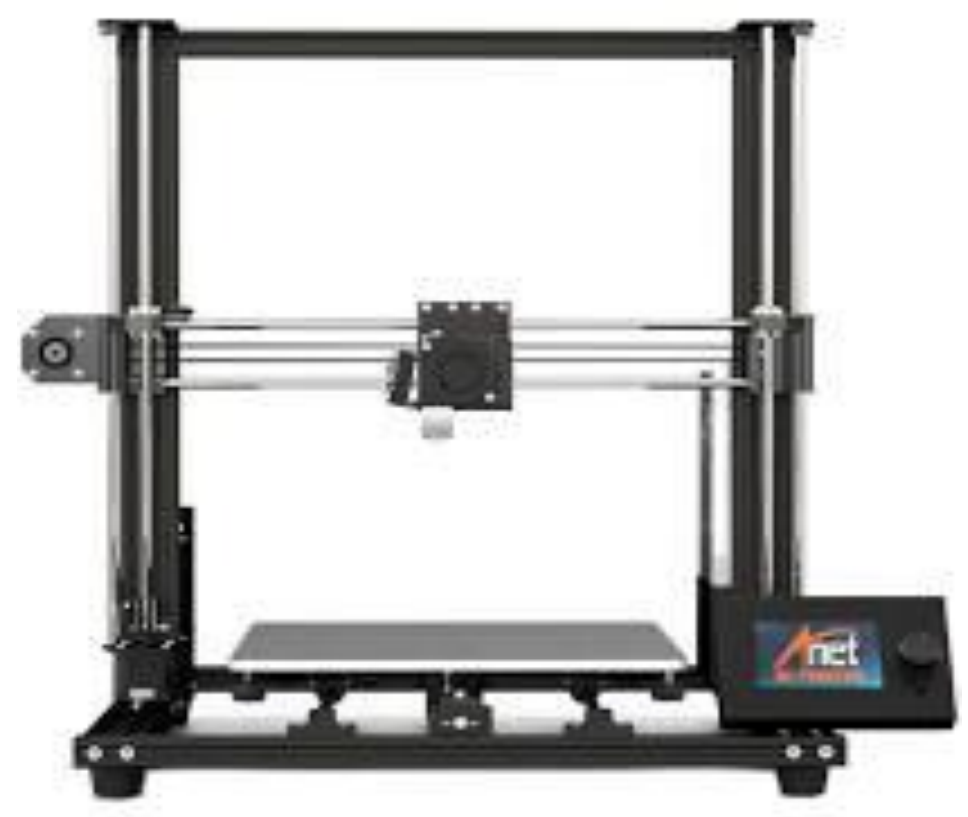

Gambar 2. Mesin 3D Printing FDM Anet 8 Plus 


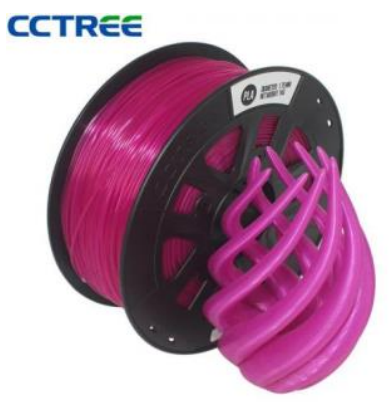

(a)

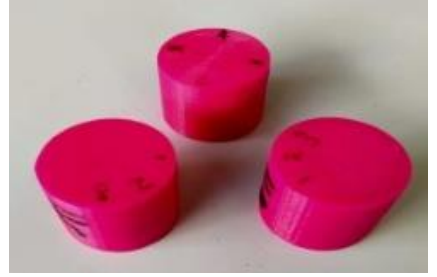

(b)

Gambar 3. (a) Filamen ST-PLA dan (b) Spesimen Uji

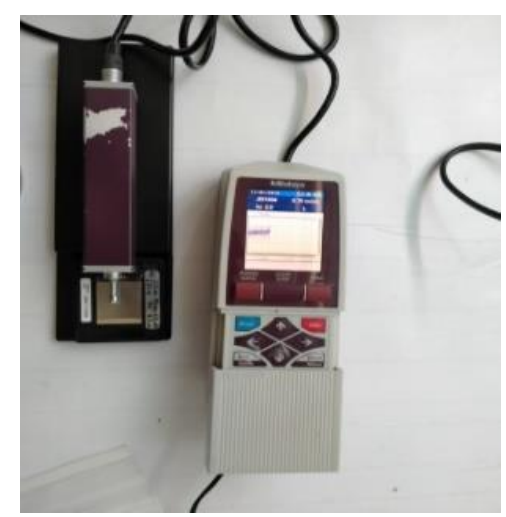

Gambar 4. Mitutoyo Surface Roughness tester

\subsection{Jenis dan Sumber Data}

Jenis data yang diperlukan dalam melakukan penelitian ini yaitu: spesifikasi mesin 3D Printer berteknologi FDM yang akan digunakan untuk mencetak spesimen uji, karakteristik dan jenis filamen yang digunakan pada penelitian ini, nilai dari setiap faktor yang akan diuji, data hasil uji kekasaran permukaan dari spesimen uji yang dicetak (bagian atas spesimen uji).

\subsection{Langkah - langkah Penelitian}

Tahapan pada penelitian ini berurutan dimulai dengan persiapan Mesin 3D Printing, filament ST PLA, software ideamaker 3.6.1 dan software gambar, semua alat dan bahan yang berhubungan dengan penelitian ini akan disiapkan sebaik mungkin agar proses penelitian terarah dan sistematis sesuai yang direncanakan. Setelah persiapan selesai dilakukan, maka akan dilanjutkan dengan menentukan parameter proses cetak yang diatur pada slicing software seperti layer thickness, printing speed, nozzle temperature, orientation, flowrate dan cooling speed seperti pada Tabel 1.

Tabel 1. Nilai Parameter yang Akan Diuji

\begin{tabular}{ccccccc}
\hline NO & $\begin{array}{c}\text { Layer thickness } \\
(\mathbf{m m})\end{array}$ & $\begin{array}{c}\text { Printing speed } \\
(\mathbf{m m} / \mathbf{s})\end{array}$ & $\begin{array}{c}\text { Nozzle Temperature } \\
\left({ }^{\circ} \mathbf{C}\right)\end{array}$ & $\begin{array}{c}\text { Orientation } \\
\left({ }^{\circ}\right)\end{array}$ & $\begin{array}{c}\text { Flow rate } \\
(\%)\end{array}$ & $\begin{array}{c}\text { Cooling speed } \\
(\%)\end{array}$ \\
\hline 1 & 0,10 & 40 & 190 & 0 & 90 & 20 \\
2 & 0,10 & 45 & 195 & 22,5 & 95 & 40 \\
3 & 0,10 & 50 & 200 & 45 & 100 & 60 \\
4 & 0,10 & 55 & 205 & 67,5 & 105 & 80 \\
5 & 0,10 & 60 & 210 & 90 & 110 & 100 \\
6 & 0,15 & 40 & 195 & 45 & 105 & 100 \\
7 & 0,15 & 45 & 200 & 67,5 & 110 & 20
\end{tabular}




\begin{tabular}{|c|c|c|c|c|c|c|}
\hline NO & $\begin{array}{l}\text { Layer thickness } \\
\text { (mm) }\end{array}$ & $\begin{array}{c}\text { Printing speed } \\
(\mathrm{mm} / \mathrm{s})\end{array}$ & $\begin{array}{c}\text { Nozzle Temperature } \\
\left({ }^{\circ} \mathrm{C}\right)\end{array}$ & $\begin{array}{l}\text { Orientation } \\
\left({ }^{\circ}\right)\end{array}$ & $\begin{array}{c}\text { Flow rate } \\
(\%)\end{array}$ & $\begin{array}{c}\text { Cooling speed } \\
(\%)\end{array}$ \\
\hline 8 & 0,15 & 50 & 205 & 90 & 90 & 40 \\
\hline 9 & 0,15 & 55 & 210 & 0 & 95 & 60 \\
\hline 10 & 0,15 & 60 & 190 & 22,5 & 100 & 80 \\
\hline 11 & 0,20 & 40 & 200 & 90 & 95 & 80 \\
\hline 12 & 0,20 & 45 & 205 & 0 & 100 & 100 \\
\hline 13 & 0,20 & 50 & 210 & 22,5 & 105 & 20 \\
\hline 14 & 0,20 & 55 & 190 & 45 & 110 & 40 \\
\hline 15 & 0,20 & 60 & 195 & 67,5 & 90 & 60 \\
\hline 16 & 0,25 & 40 & 205 & 22,5 & 110 & 60 \\
\hline 17 & 0,25 & 45 & 210 & 45 & 90 & 80 \\
\hline 18 & 0,25 & 50 & 190 & 67,5 & 95 & 100 \\
\hline 19 & 0,25 & 55 & 195 & 90 & 100 & 20 \\
\hline 20 & 0,25 & 60 & 200 & 0 & 105 & 40 \\
\hline 21 & 0,30 & 40 & 210 & 67,5 & 100 & 40 \\
\hline 22 & 0,30 & 45 & 190 & 90 & 105 & 60 \\
\hline 23 & 0,30 & 50 & 195 & 0 & 110 & 80 \\
\hline 24 & 0,30 & 55 & 200 & 22,5 & 90 & 100 \\
\hline 25 & 0,30 & 60 & 205 & 45 & 95 & 20 \\
\hline
\end{tabular}

Tahapan selanjutnya file gambar diolah pada slicing software (ideamaker 3.6.1), tujuan dari proses ini adalah agar desain yang sudah disiapkan dapat dibuat dan diproses dengan mudah oleh mesin 3D Printer yang telah disiapkan. Setelah file gambar diproses pada slicing software sehingga menghasilkan G-Code. G-Code tersebut selanjutnya disimpan pada sd.card, dan dipasangkan pada mesin 3D Printer untuk selanjutnya dicetak masing-masing tiga buah. Proses pencetakan spesimen uji kekasaran permukaan atas (Top Surface) menggunakan mesin 3D Printer ditunjukkan pada Gambar 5.

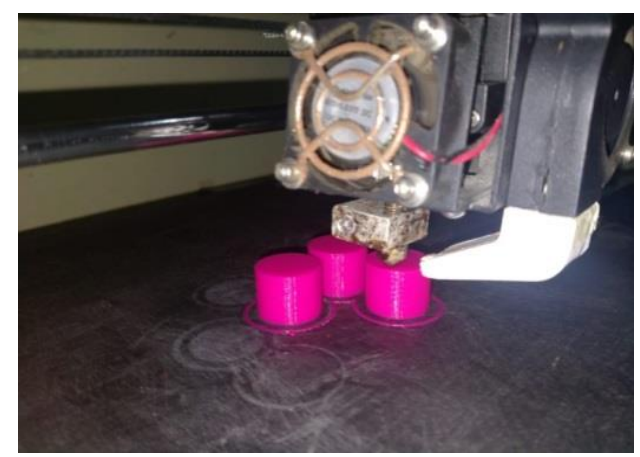

Gambar 5. Proses Pembentukan Spesimen Uji Kekasaran Permukaan Atas (Top Surface)

Setelah seluruh spesimen uji tercetak, maka tahapan selanjutnya adalah melakukan uji kekasaran permukaan Top surface dengan menggunakan alat Mitutoyo Surface Roughnes Tester untuk mengukur tingkat kekasaran permukaan untuk mengetahui kekasaran permukaan spesimen uji menggunakan material ST-PLA. Berikut merupakan titik pengambilan data nilai kekasaran permukaan spesimen (Top Surface) ditunjukkan pada Gambar 6 dan Gambar 7.

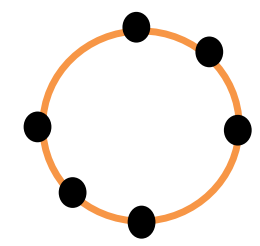

Gambar 6. Titik yang Diuji Top Surface 
Hasdiansah dkk. /Jurnal Rekayasa Mesin p-ISSN: 1411-6863, e-ISSN: 2540-7678

Vol.16|No.3|318-328|Desember|2021

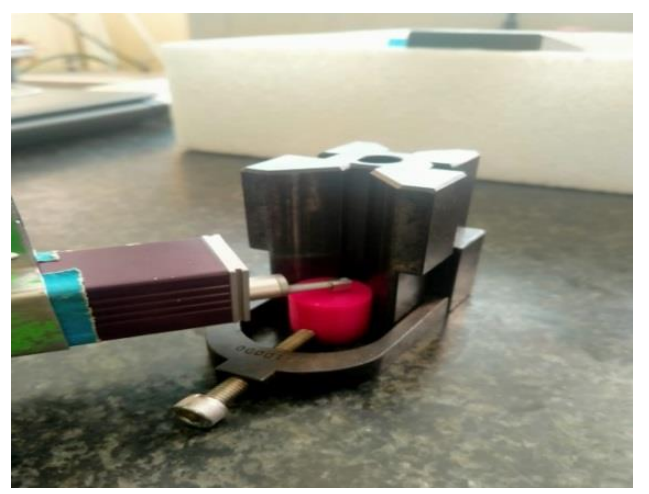

Gambar 7. Proses Pengujian Top Surface Spesimen Uji

\section{Hasil dan Pembahasan}

Data hasil pengukuran kekasaran permukaan dicatat dan dianalisis. Pengambilan data penelitian dilakukan dengan cara mengkombinasikan parameter-parameter proses yang terdapat pada mesin 3D Printer berdasarkan data G-Code yang telah dihasilkan oleh slicing software. Adapun parameter-parameter proses yang berpengaruh terhadap kekasaran permukaan adalah layer thickness, printing speed, nozzle temperature, orientation, flowrate \& cooling speed. Data hasil pengujian kekasaran ditunjukkan pada Tabel 2.

Tabel 2. Hasil Pengujian Kekasaran Permukaan Top Surface

\begin{tabular}{|c|c|c|c|c|c|c|c|c|c|}
\hline \multirow[b]{2}{*}{$\begin{array}{l}\text { Exp. } \\
\text { No. }\end{array}$} & \multicolumn{6}{|c|}{ Parameter Proses } & \multicolumn{3}{|c|}{ Nilai Kekasaran Top Surface } \\
\hline & $\begin{array}{c}\text { Layer } \\
\text { thickness } \\
(\mathrm{mm})\end{array}$ & $\begin{array}{c}\text { Printing } \\
\text { speed } \\
(\mathrm{mm} / \mathrm{s})\end{array}$ & $\begin{array}{c}\text { Nozzle } \\
\text { temperature } \\
\left({ }^{\circ} \mathrm{C}\right)\end{array}$ & $\begin{array}{c}\text { Orientation } \\
\left({ }^{\circ}\right)\end{array}$ & $\begin{array}{c}\text { Flowrate } \\
(\%)\end{array}$ & $\begin{array}{c}\text { Cooling } \\
\text { speed } \\
(\%)\end{array}$ & $\mathbf{A}$ & B & $\mathbf{C}$ \\
\hline 1 & 0,10 & 40 & 190 & 0,0 & 90 & 20 & 12,872 & 13,235 & 12,232 \\
\hline 2 & 0,10 & 45 & 195 & 22,5 & 95 & 40 & 11,332 & 12,840 & 11,739 \\
\hline 3 & 0,10 & 50 & 200 & 45,0 & 100 & 60 & 14,661 & 14,088 & 14,662 \\
\hline 4 & 0,10 & 55 & 205 & 67,5 & 105 & 80 & 12,334 & 13,384 & 12,894 \\
\hline 5 & 0,10 & 60 & 210 & 90,0 & 110 & 100 & 13,352 & 12,859 & 11,621 \\
\hline 6 & 0,15 & 40 & 195 & 45,0 & 105 & 100 & 14,124 & 15,321 & 15,451 \\
\hline 7 & 0,15 & 45 & 200 & 67,5 & 110 & 20 & 13,842 & 13,258 & 13,590 \\
\hline 8 & 0,15 & 50 & 205 & 90,0 & 90 & 40 & 17,282 & 15,919 & 13,632 \\
\hline 9 & 0,15 & 55 & 210 & 0,0 & 95 & 60 & 14,375 & 13,353 & 13,819 \\
\hline 10 & 0,15 & 60 & 190 & 22,5 & 100 & 80 & 16,134 & 16,588 & 16,021 \\
\hline 11 & 0,20 & 40 & 200 & 90,0 & 95 & 80 & 18,191 & 17,087 & 15,158 \\
\hline 12 & 0,20 & 45 & 205 & 0,0 & 100 & 100 & 16,134 & 15,169 & 15,881 \\
\hline 13 & 0,20 & 50 & 210 & 22,5 & 105 & 20 & 18,191 & 15,953 & 14,887 \\
\hline 14 & 0,20 & 55 & 190 & 45,0 & 110 & 40 & 16,974 & 16,788 & 13,520 \\
\hline 15 & 0,20 & 60 & 195 & 67,5 & 90 & 60 & 14,342 & 17,878 & 15,956 \\
\hline 16 & 0,25 & 40 & 205 & 90,0 & 110 & 60 & 15,284 & 16,615 & 18,903 \\
\hline 17 & 0,25 & 45 & 210 & 0,0 & 90 & 80 & 17,489 & 17,794 & 17,804 \\
\hline 18 & 0,25 & 50 & 190 & 67,5 & 95 & 100 & 18,110 & 16,792 & 17,775 \\
\hline 19 & 0,25 & 55 & 195 & 90,0 & 100 & 20 & 16,424 & 19,477 & 21,239 \\
\hline 20 & 0,25 & 60 & 200 & 0,0 & 105 & 40 & 16,641 & 18,901 & 17,096 \\
\hline 21 & 0,30 & 40 & 210 & 67,5 & 100 & 40 & 18,088 & 20,282 & 18,657 \\
\hline 22 & 0,30 & 45 & 190 & 90,0 & 105 & 60 & 19,482 & 20,145 & 21,343 \\
\hline 23 & 0,30 & 50 & 195 & 0,0 & 110 & 80 & 19,837 & 19,315 & 19,202 \\
\hline 24 & 0,30 & 55 & 200 & 22,5 & 90 & 100 & 18,898 & 19,183 & 20,447 \\
\hline 25 & 0,30 & 60 & 205 & 45,0 & 95 & 20 & 19,764 & 19,610 & 19,910 \\
\hline \multicolumn{7}{|c|}{ Nilai Kekasaran Terbaik } & \multicolumn{3}{|c|}{ Exp.5 } \\
\hline \multicolumn{7}{|c|}{ Nilai Kekasaran Terburuk } & \multicolumn{3}{|c|}{ Exp.22 } \\
\hline
\end{tabular}


Hasdiansah dkk. /Jurnal Rekayasa Mesin p-ISSN: 1411-6863, e-ISSN: 2540-7678

Vol.16|No.3|318-328|Desember|2021

\subsection{Perhitungan Respon Signal to Noise}

Berdasarkan data yang telah diperoleh, langkah selanjutnya adalah menghitung nilai dari rasio S/N pada tiap parameter dengan karakteristik smaller the better dan berikut diperoleh hasil perhitungan respon dapat dilihat pada Gambar 8 dan Tabel 3. Berdasarkan data pada eksperimen nomor lima (Exp. No. 5), menunjukkan bahwa nilai rata-rata kekasaran permukaan objek cetak sebesar 12,610 $\mu \mathrm{m}$. Nilai kekasaran permukaan ini merupakan hasil terbaik dari seluruh eksperimen yang telah dilakukan pada penelitian ini.Sementara hasil terburuk ditunjukkan pada ekseperimen nomor 22 (Exp. No.22) dengan nilai rata-rata kekasaran permukaan sebesar 20,333 $\mu \mathrm{m}$.

Berdasarkan Gambar 8 dan Tabel 3. diperoleh nilai level dari tiap parameter proses yang menghasilkan nilai kekasaran permukaan terbaik terhadap permukaan objek cetak (Top Surface) yaitu pada pengaturan layer thickness $0,10 \mathrm{~mm}$, flowrate $110 \%$, nozzle temperature $210^{\circ} \mathrm{C}$, printing speed $45 \mathrm{~mm} / \mathrm{s}$, cooling speed $40 \%$ dan orientation $0^{\circ}$ pada slicing software.

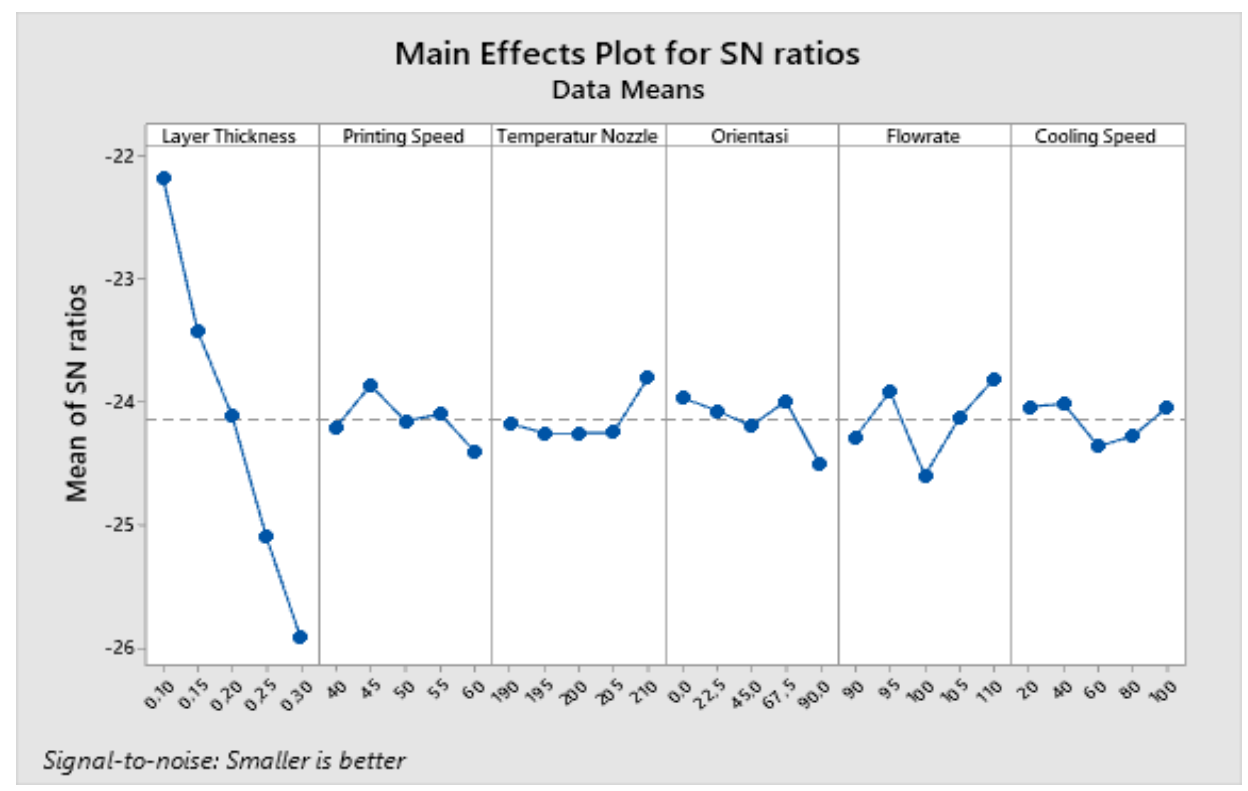

Gambar 8. Plot rasio S/N Untuk Respon Kekasaran Permukaan

Tabel 3. Rasio S/N Respon Kekasaran Permukaan

\begin{tabular}{crrrrrr}
\hline & \multicolumn{2}{c}{$\begin{array}{c}\text { Layer } \\
\text { Level }\end{array}$} & $\begin{array}{c}\text { Printing } \\
\text { Thickness }\end{array}$ & Nozzle Temperature & Orientation & \multicolumn{2}{c}{ Flowrate } & $\begin{array}{c}\text { Cooling } \\
\text { Speed }\end{array}$ \\
\hline 1 & $-22,19$ & $-24,21$ & $-24,18$ & $-23,97$ & $-24,29$ & $-24,04$ \\
2 & $-23,42$ & $-23,86$ & $-24,25$ & $-24,07$ & $-23,92$ & $-24,01$ \\
3 & $-24,11$ & $-24,15$ & $-24,25$ & $-24,19$ & $-24,59$ & $-24,36$ \\
4 & $-25,09$ & $-24,10$ & $-24,25$ & $-23,99$ & $-24,12$ & $-24,28$ \\
5 & $-25,91$ & $-24,41$ & $-23,80$ & $-24,51$ & $-23,81$ & $-24,04$ \\
\hline Delta & 3,72 & 0,54 & 0,45 & 0,54 & 0,79 & 0,34 \\
\hline Rank & 1 & 4 & 5 & 3 & 2 \\
\hline
\end{tabular}

\subsection{Hasil Analisis Variansi (ANOVA)}

Tabel 4. Hasil Analisis Variansi (ANOVA)

\begin{tabular}{ccccc}
\hline Parameter & V & SS & MS & F \\
\hline Layer Thickness & 4 & 41,59 & 10,39 & 129,96 \\
Printing Speed & 4 & 0,75 & 0,1875 & 2,34 \\
\hline
\end{tabular}


Hasdiansah dkk. /Jurnal Rekayasa Mesin p-ISSN: 1411-6863, e-ISSN: 2540-7678

Vol.16|No.3|318-328|Desember|2021

\begin{tabular}{ccccc}
\hline Nozzle Temperature & 4 & 0,74 & 0,185 & 2,31 \\
Orientation & 4 & 0,97 & 0,24 & 3,03 \\
Flowrate & 4 & 1,92 & 0,48 & 6 \\
Cooling Speed & 4 & 0,5 & 0,125 & 1,56 \\
Error & 0 & 0,32 & - & \\
\hline Total & 24 & 46,79 & & \\
\hline
\end{tabular}

Hipotesis pengujian adalah jika $\mathrm{H}_{0}=$ tidak ada pengaruh dan $\mathrm{H}_{1}=$ ada pengaruh dengan kriteria pengujian tolak $\mathrm{H}_{0}$, jika nilai $\mathrm{F}$ hitung $>\mathrm{F}$ tabel $(\alpha=5 \%)$. Hasil dari analisis dari Tabel 4 dapat dilihat pada Tabel 5 berikut. Berdasarkan data pada Tabel 5. menunjukkan bahwa nilai $\mathrm{F}$ hitung dari parameter layer thickness, flowrate dan orientation lebih besar dibandingkan dengan nilai $\mathrm{F}$ tabel yang berarti ketiga parameter tersebut berpengaruh terhadap kekasaran permukaan spesimen (Top Surface).

Tabel 5. Keputusan Uji

\begin{tabular}{cccc}
\hline Parameter & F hitung & $\begin{array}{c}\text { F Tabel } \\
(\mathbf{0 , 0 5} ; \mathbf{4 ; 2 4})\end{array}$ & Keputusan Uji \\
\hline Layer Thickness & 129,96 & & $\mathrm{H}_{0}$ ditolak \\
Printing Speed & 2,34 & & $\mathrm{H}_{0}$ diterima \\
Nozzle Temperature & 2,31 & & $\mathrm{H}_{0}$ diterima \\
Orientation & 3,03 & 2,78 & $\mathrm{H}_{0}$ ditolak \\
Flowrate & 6 & & $\mathrm{H}_{0}$ ditolak \\
Cooling Speed & 1,56 & & $\mathrm{H}_{0}$ diterima \\
\hline
\end{tabular}

\section{Kesimpulan}

Berdasarkan hasil pengukuran dengan menggunakan alat ukur Surftest, maka diperoleh bahwa parameter proses yang memberikan pengaruh paling besar terhadap kekasaran permukaan (Top Surface Roughness) dengan menggunakan filamen ST-PLA terhadap objek cetak berbentuk silinder pejal adalah layer thickness dengan nilai $\mathrm{F}$ hitung sebesar 129,96, flow rate dengan nilai F hitung sebesar enam (6) dan orientation dengan nilai F hitung sebesar 3,03. Seting parameter proses yang menghasilkan kekasaran permukaan terbaik pada permukaan atas (Top Surface) spesimen uji adalah pada pengaturan parameter layer thickness sebesar $0,10 \mathrm{~mm}$, printing speed pada $45 \mathrm{~mm} / \mathrm{s}$, nozzle temperature $210^{\circ} \mathrm{C}$, flowrate sebesar $110 \%$, sudut orientasi pencetakan objek sebesar $0^{\circ}$, dan kecepatan pendinginan (cooling speed) sebesar 40\%. Berdasarkan data hasil pengukuran terhadap eksperimen nomor lima (Exp. No. 5), menunjukkan bahwa nilai rata-rata kekasaran permukaan objek cetak sebesar 12,610 $\mu \mathrm{m}$. Nilai kekasaran permukaan ini merupakan hasil terbaik dari seluruh eksperimen yang telah dilakukan pada penelitian ini. Sementara hasil terburuk ditunjukkan pada ekseperimen nomor 22 (Exp. No.22) dengan nilai rata-rata kekasaran permukaan sebesar 20,333 $\mu$ m.

\section{Daftar Pustaka}

1. Suzen Z.S., Hasdiansah H. Pengaruh Geometri Infill terhadap Kekuatan Tarik Spesimen Uji Tarik ASTM D638 T ype IV Menggunakan Filamen PLA+ Sugoi. Jurnal Rekayasa Mesin [Internet]. Politeknik Negeri Semarang; 2021 Aug 27;16(2):140. Available from: http://dx.doi.org/10.32497/jrm.v16i2.2343

2. Altan M, Eryildiz M, Gumus B, Kahraman Y. Effect of process parameters on the quality of PLA products fabricat ed by fused deposition modelling (FDM): surface roughness and tensile strength Material Testing. 2018;60(5):471 -477.https://doi.org/10.3139/120.111178 
Hasdiansah dkk. /Jurnal Rekayasa Mesin p-ISSN: 1411-6863, e-ISSN: 2540-7678

Vol.16|No.3|318-328|Desember|2021

3. Hafsa MN, Ibrahim M, Wahab MdS, Zahid MS. Evaluation of FDM Pattern with ABS and PLA Material. AMM 2 013;465-466:55-9. https://doi.org/10.4028/www.scientific.net/amm.465-466.55.

4. Buj-Corral I, Sanchez-Casas X, Luis-Perez CJ. Analysis of AM Parameters on Surface Roughness Obtained in PL A Parts Printed with FFF Technology. Polimers [Internet] 2021;13:2384. Available from: http://dx.doi.org/10.339 0/polym13142384

5. Charles A, Elkaseer A, Thijs L, Hagenmeyer V, Scholz S. Effect of Process Parameter on the Genertated Surface Rouhness of Down-Facing Surfaces in Selective Laser Melting. Aplied Sciences [Internet] 2019;9:1256. Available from: http://dx.doi.org/10.3390/app9061256

6. García Plaza E, Núñez López P, Caminero Torija M, Chacón Muñoz J. Analysis of PLA Geometric Properties Pro cessed by FFF Additive Manufacturing: Effects of Process Parameters and Plate-Extruder Precision Motion. Poly mers [Internet] 2019;11(10):1581. Available from: http://dx.doi.org/10.3390/polym11101581

7. Taufik, I., Budiono, S. H., Herianto \& Andriyansyah, D., 2020. Pengaruh Printing Speed Terhadap Tingkat Kekas aran Permukaan Hasil Additive Manufacturing Dengan Polylactic Acid Filament. Mechanical Engineering, 4(1), p p. $15-20$.

8. Pristiansyah P, Hasdiansah H, Sugiyarto S. Optimasi Parameter Proses 3D Printing FDM Terhadap Akurasi Dime nsi Menggunakan Filament Eflex. Manutech [Internet]. 2019Jul.31 [cited 2021Dec.1];11(01):33-40. Available fro m: https://ejournal.polman-babel.ac.id/index.php/manutech/article/view/98

9. Hakim, R., Saputra, I., Utama, G. P. \& Setyoadi, 2019. Pengaruh Temperatur Nozzle dan Base Plate pada Mateial PLA Terhadap Nilai Masa Jenis dan Kekasaran Permukaan Produk Pada Mesin Leapfrog Creatr 3D Printer. Jatra Jurnal Teknologi dan Riset Terapan, 1(1), pp. 1-8.

10. Karuniawan, B. W., Rachman, F. \& Setiawan, A. A., 2019. Optimasi Parameter Mesin Fused Deposition Modellin g (FDM) Terhadap Kekasaran Permukaan Produk Menggunakan Metode Taguchi. Techno Bahari, 6(2), pp. 23-29.

11. Sahputra, B., Hakim, R. \& Saputra, I., 2018. Studi Parameter Temperatur Nozzle dan Base Plate pada Materiak A BS Sebagai Bahan Baku 3D Printer Terhadap Kehalusan Permukaan. pp. 1-10.

12. Yang, L., Li, S., Li, Y. et al. Experimental Investigations for Optimizing the Extrusion Parameters on FDM PLA P rinted Parts. J. of Materi Eng and Perform 28, 169-182 (2019). https://doi.org/10.1007/s11665-018-3784-x.

13. Nadir Ayrilmis. Effect of layer thickness on surface properties of 3D printed materials produced from wood flour/ PLA filament, Polymer Testing, Volume 71, 2018, Pages 163-166, ISSN 0142-9418, https://doi.org/10.1016/j.poly mertesting.2018.09.009.

14. Yang H, Ji F, Li Z, Tao S. Preparation of Hydrophobic Surface on PLA and ABS by Fused Deposition Modeling. Polymers [Internet] 2020;12(7):1539. Available from: http://dx.doi.org/10.3390/polym12071539.

15. Heshmat, M. and Abdelrhman, Y. (2021), "Improving surface roughness of polylactic acid (PLA) products manufa ctured by 3D printing using a novel slurry impact technique", Rapid Prototyping Journal, Vol. 27 No. 10, pp. 179 1-1800. https://doi.org/10.1108/RPJ-09-2020-0227 